\title{
Appendix
}

\section{Articles on Ireland in National Geographic magazine}

1915 December A. C. Cutler, 'British Isles', 28, 6: 551-66.

1927 March D. Byrne, 'Ireland: the rock whence I was hewn', 51, 3: 257-316.

1931 June R. Cushman Murphy, 'The timeless Arans - the workaday world lies beyond the horizon of three rocky islets off the Irish coast', 59, 6: 747-75.

1935 November $\quad$ B. F. Rogers, 'The mist and sunshine of Ulster', 68, 5: 571-610.

1940 May H. Howell Walker, 'Old Ireland, mother of new Eire: by whatever name, 'tis the same fair land with grass growing green on the hills of her and the peat smoke hanging low', 77, 5: 649-91.

1943 August 'Yanks in Northern Ireland', 84, 2: 191-204.

1951 May D. Sheats, 'I walked some Irish miles', 99, 5: 653-78.

1961 March H. V. Morton, 'The magic road round Ireland', 119, 3: 293-333.

1964 August R. L. Conly, 'Northern Ireland from Derry to Down', 126, 2: $232-67$.

1969 September J. Scofield, 'The friendly Irish', 136, 3: 354-91.

1971 April V. Thomas, 'The Arans, Ireland's invincible isles', 139, 4: 545-72.

1976 April B. Hodgson, 'Irish ways live on in Dingle', 149, 4: 551-76.

1978 November A. J. Fisher Jr., 'Where the river Shannon flows', 154, 5: 652-79.

1981 April J. Judge, 'The travail of Ireland', 159, 4: 432-41.

1981 April J. J. Putnam, 'A new day for Ireland', 159, 4: 442-99.

1994 September R. Conniff, 'Ireland on fast forward', 186, 3: 2-36.

1996 April L. Moore LaRoe, 'The Aran Islands: ancient hearts, modern minds', 189, 4: 118-33.

2005 March J. Holland, 'Beneath Irish Isles', 207, 3: 58-71. 